\title{
Detection of HIV-I RNA/DNA and CD4 mRNA in feces and urine from chronic HIV-I infected subjects with and without anti-retroviral therapy
}

\author{
Ayan K Chakrabarti, Lori Caruso, Ming Ding, Chengli Shen, \\ William Buchanan, Phalguni Gupta, Charles R Rinaldo and Yue Chen*
}

\author{
Address: Department of Infectious Diseases and Microbiology, Graduate School of Public Health, University of Pittsburgh, Pittsburgh, \\ Pennsylvania 15261, USA \\ Email: Ayan K Chakrabarti - akc1@pitt.edu; Lori Caruso - lcaruso@pitt.edu; Ming Ding - mding@pitt.edu; Chengli Shen - chs97@pitt.edu; \\ William Buchanan - bill@stophiv.pitt.edu; Phalguni Gupta - pgupta1@pitt.edu; Charles R Rinaldo - rinaldo@pitt.edu; \\ Yue Chen* - cheny@pitt.edu \\ * Corresponding author
}

Published: 2 October 2009

AIDS Research and Therapy 2009, 6:20 doi:10.1186/1742-6405-6-20

This article is available from: http://www.aidsrestherapy.com/content/6/I/20

(c) 2009 Chakrabarti et al; licensee BioMed Central Ltd.

This is an Open Access article distributed under the terms of the Creative Commons Attribution License (http://creativecommons.org/licenses/by/2.0), which permits unrestricted use, distribution, and reproduction in any medium, provided the original work is properly cited.
Received: 7 July 2009

Accepted: 2 October 2009

\begin{abstract}
HIV-I infects gut associated lymphoid tissues (GALT) very early after transmission by multiple routes. The infected GALT consequently serves as the major reservoir for HIV-I infection and could constantly shed HIV-I and CD4 ${ }^{+} \mathrm{T}$ cells into the intestinal lumen. To examine this hypothesis, we monitored HIV-I RNA/DNA and CD4 mRNA in fecal samples of chronically infected subjects with and without antiretroviral therapy (ART). We compared this to levels of HIV-I RNA/DNA in urine and blood from the same subjects. Our results show that HIV-I DNA, RNA and CD4 mRNA were detected in $8 \%, 19 \%$ and $31 \%$ respectively, of feces samples from infected subjects with detectable plasma viral load, and were not detected in any of subjects on ART with undetectable plasma viral load. In urine samples, HIV-I DNA was detected in $24 \%$ of infected subjects with detectable plasma viral load and $23 \%$ of subjects on ART with undetectable plasma viral load. Phylogenetic analysis of the envelope sequences of HIV-I revealed distinct virus populations in concurrently collected serum, feces and urine samples from one subject. In addition, our study demonstrated for the first time the presence of CD4 mRNA in fecal specimens of HIV-I infected subjects, which could be used to assess GALT pathogenesis in HIV-I infection.
\end{abstract}

\section{Introduction}

Gut-Associated Lymphoid Tissues (GALT) are very important in HIV pathogenesis. GALT is the largest single immunologic organ in the body, containing a large amount of lymphocytes. Contrast to the blood and other organized lymphoid tissues, which contain abundance of naive resting $\mathrm{T}$ cells, a majority of the $\mathrm{CD} 4{ }^{+} \mathrm{T}$ cells that reside in GALT are CCR5 positive, activated memory CD $4 \mathrm{~T}$ cells which are the preferred target cells for HIV/SIV infection [1-3]. HIV infects GALT at a very early stage of infection regardless of the route of infection and active HIV/SIV replication in GALT is present throughout the entire course of infection, which leads to GALT acting as a major viral reservoir and results in mucosal barrier dysfunction and bacterial translocation that contributes to generalized systemic immune activation and disease progression[2-6]. 
$\mathrm{CD} 4{ }^{+} \mathrm{T}$ cells in the gut are rapidly infected and depleted soon after infection $[3,7]$ and $\mathrm{CD} 4^{+} \mathrm{T}$ cell repopulation of the gut is prevented throughout infection[4]. We hypothesize that during HIV-1 infection, HIV-1 free virus and infected/uninfected CD4+ $\mathrm{T}$ cells constantly shed from GALT into the intestinal lumen and are discharged with feces. Therefore, the amount of HIV-1 and CD4 ${ }^{+} \mathrm{T}$ cells contained in the feces could reveal the degree of pathogenesis in GALT. Detection of HIV-1 has been reported in fecal specimens from drug naïve HIV-1 infected individuals in the acute phase of infection [8-10]. There is no information on HIV-1 detection in the feces of chronically infected subjects, especially in subjects undergoing antiretroviral drug therapy (ART). Monitoring the dynamic change of CD4+ $\mathrm{T}$ cells in GALT of infected individuals is very important to evaluate disease progression. However, due to the anatomic location of GALT, invasive and expensive biopsy is the only current method to monitor $\mathrm{CD} 4^{+} \mathrm{T}$ cell loss in GALT. In contrast, feces could be an easily accessible, non-invasive and inexpensive specimen to assess $\mathrm{CD} 4^{+} \mathrm{T}$ cell depletion of GALT, since CD4 ${ }^{+}$ $\mathrm{T}$ cells could shed into the intestinal lumen and be discharged in feces.

HIV-1 from seropositive individuals has been detected from various body fluids including blood, semen, tears, saliva, cerebrospinal fluid, breast milk and cervical secretions[11]. A broad spectrum of renal diseases has been reported in HIV-1 infected AIDS subjects [12-14], yet there is little information on the presence of HIV-1 in urine. The presence of anti-HIV-1 antibodies has been reported in urine by ELISA and Western blot $[15,16]$ and HIV-1 DNA has been detected in urine pellets from HIV-1 infected individuals $[17,18]$. However, it is not clear whether urine from chronically infected persons with/ without ART contains HIV-1 DNA/RNA, and how virus in urine is related to the viral load in serum.

In this study, we detected HIV-1 RNA/DNA in fecal and urine specimens from chronically HIV-1 infected subjects with or without ART. In addition, we examined the presence of human CD4 mRNA in fecal specimens to assess $\mathrm{CD} 4^{+} \mathrm{T}$ cell loss in GALT.

\section{Materials and methods Study Participants}

The uninfected and HIV-1 infected subjects in this study were enrolled in the Multicenter AIDS Cohort Study (MACS) at Pittsburgh, PA. The MACS is an ongoing prospective natural history study of HIV-1 infection in homosexual and bisexual men enrolled at Baltimore, Chicago, Pittsburgh and Los Angeles. The study was approved by the University of Pittsburgh Institutional Review Board (IRB). Fecal specimens that were used in this study were collected in 2008. Thirty-nine samples were collected from the subjects in four different groups: Group A: HIV1 negative; Group B: HIV-1 positive but not on ART; Group C: HIV-1 positive on ART with non-detectable viral load in blood; Group D: HIV-1 positive on ART with detectable viral load in blood (Table 1).

\section{Collection and storage of biological specimens}

Fecal samples were collected in special stool collection tubes (Sarstedt) and were stored in RNAlater solution (Ambion) or Cell-Lysis buffer in -80C freezer within 6 hours of collection. Urine samples were processed within 6 hours of collection. Blood samples were collected from all study participants at the same time as feces and urine. Plasma, serum and PBMC were isolated from these blood samples and used for $\mathrm{CD}^{+} \mathrm{T}$ cell counts and viral load measurement.

\section{HIV-I infected cell line and HIV-I positive plasma}

The 8E5 cell line used in this study is derived from HIV-1 infected CD4 ${ }^{+}$CEM cells, and carries a single, integrated and RT-defective HIV-1 genome[19]. The HIV-1 positive plasma with viral load of 170,000 copies $/ \mathrm{ml}$ was obtained from a HIV-1 (subtype B) infected Brazilian blood donor. $8 \mathrm{E} 5$ cell line and HIV-1 positive plasma were added to feces from HIV-1 negative persons before nucleic acid isolation to test the detection limit of HIV-1 DNA/RNA by PCR.

\section{Extraction of RNAIDNA from feces samples}

Two hundred milligrams of feces with or without 8E5 cells was used to isolate RNA/DNA with a nucleic acid isolation kit from Biomerieux following the manufacturer's instructions. Briefly, specimens stored in $2 \mathrm{ml}$ Cell-Lysis buffer were thawed and mixed completely by vortexing. Fifty microliters of silica bead suspension was added to the fecal sample and the sample mixture was incubated at room temperature for $10 \mathrm{~min}$. with periodic vortexing and centrifuged for 3 minutes at $1500 \mathrm{~g}$. The supernatant was removed and the pellet was washed five times: 2 times with wash buffer, 2 times with $70 \%$ grade ethanol and 1 time with analytical grade acetone. The silica-nucleic acid complexes were dried on a heat block at $56^{\circ} \mathrm{C}$ for $10 \mathrm{~min}$ utes and nucleic acids were eluted using $100 \mathrm{ul}$ of elution buffer. Eluted nucleic acids were immediately stored at $70^{\circ} \mathrm{C}$ for further use.

\section{Extraction of RNAIDNA from urine samples}

$26-83 \mathrm{ml}$ of urine were collected from the study participants and processed within 6 hours. The urine samples were centrifuged at $1500 \mathrm{~g}$ for 10 minutes at $4{ }^{\circ} \mathrm{C}$. The urine pellets were saved in $-80^{\circ} \mathrm{C}$ for DNA isolation. The urine supernatant was concentrated by a Centricon plus70 filter with molecular weight cutoff $100 \mathrm{kDa}$ (Millipore) according to manufacturer's instruction. Briefly, urine supernatant was centrifuged in a pre-wet Centricon at 500 
Table I: Clinical information of 2008 MACS study participants

\begin{tabular}{|c|c|c|c|c|}
\hline & ID & Sample Date & Viral Load (copies/ml) & $\mathrm{CD} 4 / \mathrm{mm} 3$ \\
\hline \multirow[t]{10}{*}{ Group A = HIV-I Negative $N=10$} & $X X 110$ & $8 / 27 / 2008$ & $\mathrm{~N} / \mathrm{A}$ & 642 \\
\hline & $X \times 712$ & $8 / 16 / 2008$ & $\mathrm{~N} / \mathrm{A}$ & 1317 \\
\hline & $X \times 163$ & $8 / 19 / 2008$ & N/A & 899 \\
\hline & XX983 & $8 / 19 / 2008$ & N/A & 1153 \\
\hline & $X \times 27 I$ & $9 / 5 / 2008$ & N/A & 828 \\
\hline & XX003 & $9 / 16 / 2008$ & N/A & 547 \\
\hline & XX744 & $9 / 25 / 2008$ & N/A & 1520 \\
\hline & $X \times 186$ & $9 / 24 / 2008$ & N/A & 839 \\
\hline & $X X \mid 48$ & $9 / 17 / 2008$ & N/A & 724 \\
\hline & XX02I & $8 / 19 / 2008$ & $\mathrm{~N} / \mathrm{A}$ & 845 \\
\hline \multirow{11}{*}{$\begin{array}{l}\text { Group B = HIV-I Positive/No antiretroviral treatment } \\
(\text { ART) } N=I I\end{array}$} & $X \times 280$ & $8 / 26 / 2008$ & 1003 & 923 \\
\hline & XX495 & $8 / 16 / 2008$ & 35471 & 238 \\
\hline & $X \times 326$ & $8 / 23 / 2008$ & 20149 & 392 \\
\hline & XX286 & $9 / 17 / 2008$ & 2974 & 320 \\
\hline & XXII9 & $8 / 26 / 2008$ & $1823 \mid$ & 301 \\
\hline & XX200 & $8 / 26 / 2008$ & 58200 & 149 \\
\hline & XX305 & $9 / 4 / 2008$ & 582 & 388 \\
\hline & XX053 & $9 / 26 / 2008$ & 78636 & 406 \\
\hline & XX109 & $9 / 25 / 2008$ & 428 & 358 \\
\hline & $X X 013$ & $9 / 12 / 2008$ & $2044 I$ & 457 \\
\hline & XX634 & $9 / 18 / 2008$ & 6779 & 352 \\
\hline \multirow[t]{6}{*}{ Group C = HIV - I Positive/ART/Non-detectable viral load N = I3 } & XX484 & $8 / 19 / 2008$ & $<50$ & 440 \\
\hline & XX008 & $8 / 20 / 2008$ & $<50$ & 890 \\
\hline & $X \times 523$ & $9 / 5 / 2008$ & $<50$ & 696 \\
\hline & $X \times 245$ & $9 / 23 / 2008$ & $<50$ & 566 \\
\hline & $X \times 163$ & $9 / 10 / 2008$ & $<50$ & 549 \\
\hline & $X \times 690$ & $9 / 9 / 2008$ & $<50$ & 385 \\
\hline
\end{tabular}


Table I: Clinical information of 2008 MACS study participants (Continued)

\begin{tabular}{|c|c|c|c|c|}
\hline & XX005 & $8 / 28 / 2008$ & $<50$ & 777 \\
\hline & $X X 144$ & $8 / 28 / 2008$ & $<50$ & 583 \\
\hline & $X X 154$ & $8 / 20 / 2008$ & $<50$ & 922 \\
\hline & $X \times 327$ & $9 / 30 / 2008$ & $<50$ & 426 \\
\hline & $X \times 350$ & $9 / 3 / 2008$ & $<50$ & 466 \\
\hline & $X \times 263$ & $9 / 17 / 2008$ & $<50$ & 697 \\
\hline & $X \times 265$ & $9 / 25 / 2008$ & $<50$ & 478 \\
\hline \multirow[t]{5}{*}{ Group $D=$ HIV-I Positive/ART detectable viral load $N=5$} & $X \times 127$ & $9 / 3 / 2008$ & 694 & 161 \\
\hline & $X \times 229$ & $8 / 28 / 2008$ & 186 & 540 \\
\hline & XX37I & $9 / 10 / 2008$ & 33751 & 152 \\
\hline & XX099 & $9 / 23 / 2008$ & 842 & 153 \\
\hline & $X \times 274$ & 9/9/2008 & 16842 & 279 \\
\hline
\end{tabular}

g for 1.5 hrs and the concentrated supernatant was collected by inverted spinning and further concentrated by ultracentrifugation at $22,000 \mathrm{rpm}$ for one hour at $4{ }^{\circ} \mathrm{C}$. Most of the supernatant was removed and $50 \mathrm{ul}$ of remaining supernatant and pellet was saved at $-80^{\circ} \mathrm{C}$ for further RNA isolation.

RNA was purified from the remaining supernatant and pellet after ultracentrifugation using RNA-Bee RNA Isolation kit (Tel-Test) according to manufacturer's instruction. Briefly, $1 \mathrm{ml}$ of RNA-Bee solution and $200 \mathrm{ul}$ of chloroform were added to the sample and shaken vigorously for 30 seconds at room temperature. Then, the sample was incubated in $4^{\circ} \mathrm{C}$ for 5 minutes and centrifuged at 12,000 $\mathrm{g}$ for 15 minutes at $4^{\circ} \mathrm{C}$. After centrifugation, the aqueous phase containing RNA was carefully recovered. The RNA was precipitated using isopropanol, washed with $75 \%$ ethanol, air dried and stored in nuclease free water at $80^{\circ} \mathrm{C}$ for future RT-PCR work.

DNA was purified from the urine pellet using PUREGENE DNA Purification Kit (Gentra Systems) according to manufacturer's instruction. Briefly, urine pellet from initial centrifugation was resuspended in $900 \mathrm{ul}$ of Cell Lysis Solution and incubated at $65^{\circ} \mathrm{C}$ for $30 \mathrm{~min}$. After incubation, $5 \mathrm{ul}$ of RNase A Solution was added to the mixture and incubated at $37^{\circ} \mathrm{C}$ for $30 \mathrm{~min}$. Then, $300 \mathrm{ul}$ of Protein Precipitation Solution was added to the mixture and vortexed followed by centrifugation at $2000 \mathrm{~g}$ for 10 minutes.
DNA was precipitated from the supernatant by isopropanol, washed by $70 \%$ ethanol and air dried. The DNA was re-hydrated in nuclease free water and stored at $-20^{\circ} \mathrm{C}$ for subsequent PCR work.

\section{Nested PCR and RT-PCR}

Nested PCR and RT-PCR were performed on isolated RNA/DNA samples from feces and urine to detect HIV-1 RNA/DNA and CD4 mRNA. Specific primers listed in Table 2 were used for optimal detection of HIV-1 subtype B env and gag regions, human beta-globin DNA, human beta-actin mRNA and CD4 mRNA.

First a cDNA strand was generated using Superscript II RT (Invitrogen, Carlsbad, CA). A 10 ul reaction consisting of $10 \mathrm{ug}$ of RNA, $2 \mathrm{uM}$ of primer, $10 \mathrm{mM}$ dNTP mix, and $\mathrm{H} 2 \mathrm{O}$ was incubated at $70^{\circ} \mathrm{C}$ for 10 minutes. Following incubation, $5 \times$ RT buffer, $0.1 \mathrm{M}$ DTT, RNA guard (RNase) (40 U/ul), and Superscript II RT (200 U/ul) were added respectively. The reaction was incubated in a $\mathrm{H}_{2} \mathrm{O}$ bath at $42^{\circ} \mathrm{C}$ for 50 minutes followed by a second incubation in dry bath at $70^{\circ} \mathrm{C}$ for 10 minutes. Amplification of specific target sequences in the cDNA was performed using $10 \mu \mathrm{l}$ cDNA, forward and reverse primer pairs, dNTPs, Taq polymerase buffer and Taq-polymerase in thermocycler (Applied Biosystems) with cycling conditions of $94^{\circ} \mathrm{C}, 10$ min followed by 35 cycles of $94^{\circ} \mathrm{C}, 1 \mathrm{~min}, 55^{\circ} \mathrm{C}, 1 \mathrm{~min}$, $72^{\circ} \mathrm{C}, 1 \mathrm{~min}$. Presence of the amplicon was analyzed on a $1 \%-2.5 \%$ agarose gel in $1 \times$ TAE buffer. 
Table 2: The primers used for nested PCR/RT nested PCR amplification

\begin{tabular}{|c|c|c|}
\hline Name & Sequences $\left(5^{\prime} \rightarrow 3^{\prime}\right)$ & Description \\
\hline EDI 2 & AGT GCT TCC TGC TGC TCC CAA GAA CCC AAG & RT primer for HIV env gp I 20 \\
\hline ED31 & CCT CAG CCA TTA CAC AGG CCT GTC CAA AG & I st round PCR forward primer for HIV env gP I 20 \\
\hline $\mathrm{BH} 2$ & СCT TGG TGG GTG CTA СTC CTA ATG GTT CA & I $^{\text {st }}$ round PCR reverse primer for HIV env gP 120 \\
\hline DR7 & TCA ACT CAA CTG CTG TTA AAT GGC AGT CTA GC & $2^{\text {nd }}$ round PCR forward primer for HIV env gP 120 \\
\hline DR8 & САС ТTС ТСС АAT ТGT ССС ТСA ТАТ СТС СТС С & $2^{\text {nd }}$ round $P C R$ reverse primer for HIV env gP 120 \\
\hline Hu-CD4 RT primer & ATG TCT TCT GAA ACC GGT GAG GAC ACT G & RT primer for human CD4 mRNA \\
\hline Hu-CD4 outside F & CCA AGT CTT GGA TCA CCT TTG ACC TGA AG & | ${ }^{\text {st }}$ round PCR forward primer for Human CD4 CDNA \\
\hline Hu-CD4 outside R & AGA AGA AGA TGC CTA GCC CAA TGA AAA GC & I $^{\text {st }}$ round PCR reverse primer for Human CD4 cDNA \\
\hline Hu-CD4 Inside F & CTC CCG CTC CAC СТС ACC CTG & $2^{\text {nd }}$ round PCR forward primer for Human CD4 CDNA \\
\hline Hu-CD4 Inside R & CAT GTG GGC AGA ACC TTG ATG TTG G & $2^{\text {nd }}$ round PCR reverse primer for Human CD4 CDNA \\
\hline B-globin outside F & CTG CTG GTG GTC TAC CCT TGG AC & ${ }^{\text {st }}$ round $P C R$ primer for Human Beta globin DNA \\
\hline B-globin outside $R$ & CTC AAG TTC TCA GGA TCC A & $\left.\right|^{\text {st }}$ round PCR primer for Human Beta globin DNA \\
\hline B-globin inside F & GGT TCT TTG AGT CCT TTG GGG ATC & $2^{\text {nd }}$ round PCR forward primer for Human Beta globin DNA \\
\hline B-globin inside $\mathrm{R}$ & GTC ACA GTG CAG CTC ACT CAG TGT G & $2^{\text {nd }}$ round PCR reverse primer for Human Beta globin DNA \\
\hline B-actin outside $F$ & GCA CCA CAC CTT CTA CAA TG & Ist round PCR primer for Human Beta actin cDNA \\
\hline B-actin outside $R$ & TGC TTG CTG ATC CAC ATC TG & $\left.\right|^{\text {st }}$ round PCR primer for Human Beta actin cDNA \\
\hline B-actin inside $\mathrm{F}$ & TAC CAC TGG CAT CGT GAT GGA CTC & $2^{\text {nd }}$ round PCR primer for Human Beta actin cDNA \\
\hline B-actin inside $R$ & CGC TCA TTG CCA ATG GTG ATG AC & $2^{\text {nd }}$ round PCR primer for Human Beta actin cDNA \\
\hline Gag outside F & GGC CAT ATC ACC TAG AAC TTT AAA TGC ATG G & Ist $_{\text {sound } P C R}$ primer for HIV Gag \\
\hline Gag outside R & CCT ACT GGG ATA GGT GGA TTA TTT GTC ATC CA & Ist round PCR primer for HIV Gag \\
\hline Gag inside F & GGC ACA TCA AGC AGC CAT GCA AAT G & $2^{\text {nd }}$ round $\mathrm{PCR}$ primer for HIV Gag \\
\hline Gag inside $R$ & TAG TTC CTG CTA TGT CAC TTC CCC TTG G & $2^{\text {nd }}$ round $\mathrm{PCR}$ primer for HIV Gag \\
\hline
\end{tabular}

\section{Detection of fecal occult blood from feces samples}

The fecal samples were tested for presence of occult blood by a Hemoccult II SENSA kit (Beckman-Coulter). Trace amount of the fecal sample was smeared onto an absorbent paper that has been treated with a chemical guaiac. Hydrogen peroxide was dropped onto the fecal smear. If trace amounts of blood were present, a blue color developed. A total of 39 fecal specimens from the study participants (Table 1) were tested. In addition, a normal donor fecal sample was included as a negative control and normal donor fecal sample mixed with blood as a positive control.

\section{Cloning and sequencing of PCR products}

The PCR product was purified from an agarose gel and ligated into TOPO vectors (Invitrogen, Carlsbad, CA) according to manufacturer's instruction. Cloned plasmid DNA was purified from transformed E. Coli using Wizard ${ }^{\circledR}$ 
Plus Minipreps DNA Purification System (Promega, Madison, WI) and digested with EcoRI restriction enzyme to confirm the insertion. The plasmid DNAs with the insertions were then sequenced using M13 forward or M13 reverse primers. Sequences were assembled and error checked using the Vector NTI 9.0 software (Invitrogen) and aligned with reference sequences from GenBank by the ClustalW multiple sequence alignment programs from Mega 4.0.

\section{Results \\ Evaluation of the sensitivity of the PCR detection of HIV-I DNAIRNA in human feces}

To test the sensitivity of amplifying HIV-1 DNA, $200 \mathrm{mg}$ of normal donor fecal sample was mixed with different concentrations of HIV-1 positive 8E5 cells. Nucleic acid was isolated using NUCLISENS (BIOMERIEUX) nucleic acid isolation kit. For every DNA sample, the human betaglobin gene was PCR amplified to ensure that the isolated DNA was amplifiable and contained the comparable amount of human DNA. Subsequently, a nested PCR reaction was performed to detect HIV-1 DNA from the isolated DNA using HIV-1 env specific primers. HIV-1 DNA was detected from the DNA isolated from normal donor feces mixed with 8E5 cells and the detection limit was as low as 2.5 copies/reaction (data not shown).

To test the sensitivity of amplifying HIV-1 RNA, $200 \mathrm{mg}$ of normal donor feces were mixed with a series of different concentrations of HIV-1 positive plasma (with known HIV-1 RNA copies) and nucleic acid was isolated as before followed by RT nested PCR with HIV-1 env specific RT and PCR primers. As a human RNA input control in each sample, cDNA was synthesized by random hexamer followed by nested PCR amplification using human beta-actin mRNA specific primers. HIV-1 RNA was detected from normal feces mixed with HIV-1 positive plasma and the detection limit was as low as 40 copies/reaction (data not shown).

\section{Detection of HIV-I DNA/RNA in feces}

Four groups of study participants were recruited in 2008 (Table 1). Group A: 10 HIV-1 negative individuals; Group B: 11 HIV-1 infected individuals, who are drug naïve with detectable viral load in plasma ranging from 428 to 78,636 and CD4+ T cell count ranging from 149 to 923 . Group C: 13 HIV-1 infected individuals, who are on ART with undetectable viral load in plasma and CD4 ${ }^{+} \mathrm{T}$ cell count ranging from 385 to 922. Group D: 5 HIV-1 infected individuals, who are on ART with detectable viral load in plasma ranging from 186 to 33,751 and CD4+ T cell counts ranging from 152 to 540. Nucleic acids isolated from $200 \mathrm{mg}$ feces were subjected to nested-PCR for amplification of HIV-1 env C2-V5 region. For every DNA sample, the human beta-globin gene was PCR amplified to ensure the comparable amount of human DNA con- tained in each PCR reaction. The beta-globin gene was detected in 17 out of 39 fecal specimens. Among these 17 beta-globin positive samples, one was from Group A, 8 from Group B, 3 from Group C and 5 from Group D. However, HIV-1 DNA was detected only in one fecal specimen from a patient (not on ART) with detectable viral load (XX495, viral load 35,471, Group B) (data not shown).

Nucleic acids isolated from $200 \mathrm{mg}$ of fecal specimen were subjected to RT nested-PCR. To serve as the human RNA input control for each sample, human beta-actin mRNA was amplified by RT nested PCR amplification. As shown in Figure 1A, relatively equal amounts of beta-actin mRNA were detected from all isolated fecal RNA, whereas HIV-1 RNA was detected in 3 out of 16 (19\%) subjects with detectable viral load in blood (Figure 1A \&1B).

\section{Confirmation of PCR specificity by using primers for another region (gag) of HIV-I genome and sequencing the $P C R$ products after cloning into a vector}

To confirm the specificity of PCR amplification of env region in feces samples, the HIV-1 gag region was also amplified in these samples using gag specific primers. Two out of three HIV-1 env targeted-PCR positive and two out of two env negative fecal RNA samples maintained the identical outcome using gag specific primers. Furthermore, cloning and sequencing of the PCR product using env specific primers from the fecal samples demonstrated that the PCR products were HIV-1 subtype B env sequences (data not shown).

\section{Detection of human CD4 mRNA from the fecal samples}

To monitor CD4 mRNA contained in the fecal samples, nucleic acids isolated from the fecal samples were subjected to RT nested PCR using CD4 mRNA specific primers. Human CD4 mRNA specific 110 bp PCR product was detected in 5 out of 16 (32\%) subjects with detectable viral load in blood (Figure 2). Three of the detected 5 subjects were not on ART and 2 subjects were on ART. In contrast, no CD4 mRNA was detected in any HIV-1 uninfected donor's fecal specimens or infected donors with undetectable viral loads.

\section{Detection of fecal occult blood from the fecal samples}

To detect the possible blood content in the fecal samples, an occult blood test was performed in all fecal specimens as described in Materials and Methods section. As shown in Table 3, fecal blood was detected in 7 out of 39 fecal specimens: 2 from Group A, 1 from Group B, 3 from Group C and 1 from Group D. The fecal occult blood test was negative for the fecal samples which were positive for HIV-1 RNA or DNA. One of the five CD4 mRNA positive fecal specimens was positive for occult blood and the remaining samples were negative. 


\section{Human beta-actin mRNA}

\section{A}

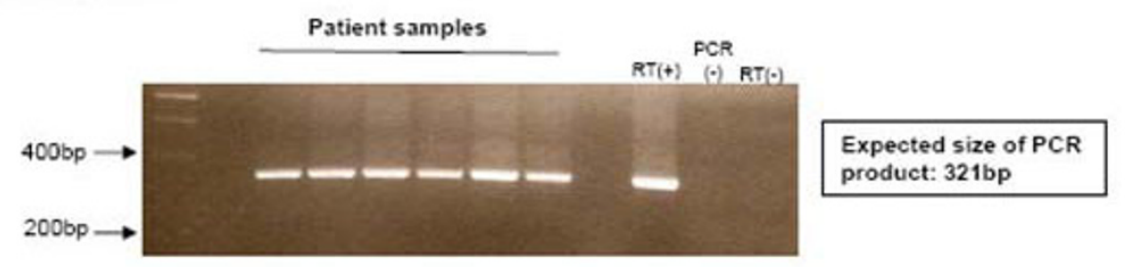

HIV-1 RNA

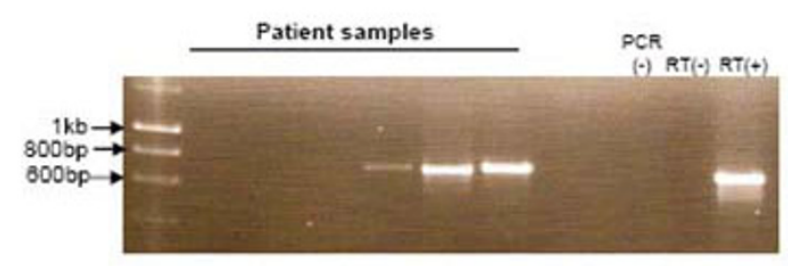

Expected size of PCR

B

\section{Figure I}

Detection of HIV-I RNA in feces collected from study participants. A: Representative gel picture of RT nested PCR products of human beta-actin mRNA. B: Representative gel picture of RT nested PCR products of HIV-I RNA.

\section{Detection of HIV-I DNA/RNA from the urine samples}

The HIV env region was amplified from the DNA purified from the urine pellet in a nested-PCR reaction using the env primers described previously. For each DNA sample, human beta-globin gene was also PCR amplified to ensure the comparable amount of human DNA contained in each PCR reaction. All 34 urine pellet samples were positive for beta-globin amplification. HIV-1 DNA was detected in 7 urine pellet samples from HIV infected subjects, 4 from subjects with detectable viral load, and 3 from subjects with undetectable viral load (Table 3 ). Furthermore, RNA purified from the 34 urine supernatants was tested by RT nested-PCR to detect HIV env region. HIV-1 RNA was detected in one urine sample from a patient with detectable viral load.
Sequence analysis of the HIV-I envelope gene amplified from serum, feces and urine samples from an HIV-I infected subject

In one subject from Group B with viral load 18,231 copies $/ \mathrm{ml}$ in blood, HIV-1 env was PCR detected in all three samples collected concurrently: serum, urine and feces. The PCR products corresponding to the $\mathrm{C}_{2}-\mathrm{V}_{5}$ region of HIV-1 env gp120 from all three compartments were cloned and sequenced to determine the viral diversity. A phylogenetic tree was constructed by the neighbor-joining method as implemented in Mega 4.0. The validity of the branching orders was estimated with 1000 replicates. Reference strains were obtained from the Los Alamos HIV database by using similar blast search. Phylogenetic analysis revealed that all the sequences belong to HIV-1 sub-

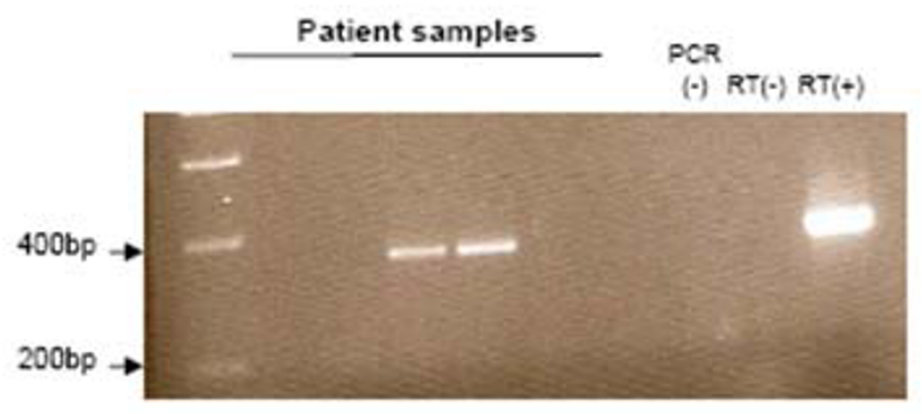

Expected size of PCR

product: $341 \mathrm{bp}$

Figure 2

Detection of CD4 mRNA in feces collected from study participants. Representative gel picture of RT nested PCR products of CD4 mRNA from the MACS donor feces. 
Table 3: Summary of detection of HIV-I RNA/DNA/human CD4 mRNA/fecal occult blood from feces and urines collected from MACS study participants in $\mathbf{2 0 0 8}$

\begin{tabular}{|c|c|c|c|c|c|c|c|c|c|}
\hline & \multirow[t]{2}{*}{ ID } & \multirow{2}{*}{$\begin{array}{l}\text { Viral Loads } \\
\text { (copies/ml) }\end{array}$} & \multirow[t]{2}{*}{$\mathrm{CD} 4 / \mathrm{mm}^{3}$} & \multicolumn{2}{|c|}{ URINE } & \multicolumn{4}{|c|}{ FECES } \\
\hline & & & & HIV-IDNA & HIV-I RNA & HIV-I DNA & HIV-I RNA & $\begin{array}{c}\text { CD4 } \\
\text { mRNA }\end{array}$ & $\begin{array}{c}\text { Fecal occult } \\
\text { blood }\end{array}$ \\
\hline \multirow{2}{*}{$\begin{array}{l}\text { Group A } \\
(N=10)\end{array}$} & $X \times 271$ & N/A & 828 & - & - & - & - & - & + \\
\hline & XX744 & N/A & 1520 & - & - & - & - & - & + \\
\hline \multirow{8}{*}{$\begin{array}{l}\text { Group B } \\
(N=I I)\end{array}$} & XX053 & 78636 & 406 & - & - & - & - & - & + \\
\hline & $X \times 280$ & 10003 & 923 & - & - & - & - & + & - \\
\hline & XX495 & $3547 I$ & 238 & - & - & + & - & - & - \\
\hline & $X \times 326$ & 20149 & 392 & - & - & - & + & - & - \\
\hline & $X X 286$ & 2974 & 320 & - & - & - & - & + & - \\
\hline & $X X 119$ & $|823|$ & 901 & - & + & - & + & + & - \\
\hline & $X \times 200$ & 85820 & 149 & + & - & - & - & - & - \\
\hline & $X \times 013$ & 20441 & 457 & + & - & - & - & - & - \\
\hline \multirow{5}{*}{$\begin{array}{l}\text { Group C } \\
(N=13)\end{array}$} & $X \times 245$ & $<50$ & 566 & - & - & - & - & - & + \\
\hline & $X X 690$ & $<50$ & 385 & - & - & - & - & - & + \\
\hline & $X \times 265$ & $<50$ & 478 & + & - & - & - & - & + \\
\hline & XX523 & $<50$ & 696 & + & - & - & - & - & - \\
\hline & $X \times 327$ & $<50$ & 426 & + & - & - & - & - & - \\
\hline \multirow{3}{*}{$\begin{array}{l}\text { Group D } \\
(N=5)\end{array}$} & XX099 & 842 & 153 & - & - & - & - & + & + \\
\hline & $X \times 274$ & 16862 & 279 & + & - & - & + & + & - \\
\hline & XX37I & 33751 & 152 & + & - & - & - & - & - \\
\hline
\end{tabular}

type B. Blood-, fecal- and urine- derived sequences formed a tightly clustered group of sequences respectively. However, the sequence analysis also showed a distributed pattern of viral variants among blood, feces and urine, indicating that distinct HIV-1 quasispecies existed in different part of tissues within the subject (Figure 3).

\section{Discussion}

Many viral pathogens have been detected in feces, such as astrovirus, rotavirus, coronavirus, calcivirus, adenovirus and hepatitis C virus[20,21]. However, no comprehensive studies have been performed so far on the fecal samples from HIV-1 infected subjects. Furthermore, no studies have evaluated HIV-1 and CD4 mRNA level in feces from subjects at chronic stages of disease with or without ART.

GALT contains an abundant amount of $\mathrm{CD} 4^{+} \mathrm{T}$ cells to maintain the mucosal immunity and is an important tissue for HIV replication in HIV infection. Ideally to monitor HIV-1 related GALT pathogenesis, a GI biopsy should 
be performed regularly to evaluate the dynamic changes of CD4 ${ }^{+} \mathrm{T}$ cells and viral load in GALT. However, such studies are very difficult and expensive to implement. We hypothesized that during the massive HIV-1 replication and $\mathrm{CD} 4{ }^{+} \mathrm{T}$ cell depletion in GALT, HIV-1 and CD4+ $\mathrm{T}$ cells shed into the intestinal lumen and the amount of HIV-1 and CD4 $4^{+} \mathrm{T}$ cells in the feces would associate with the pathogenic changes in GALT.

Since the components of human feces are very complex and so far no sensitive methods are available for detection of viral and human RNA/DNA in human feces, we have initially tested assay sensitivity for nucleic acid isolation and detection of HIV-1 DNA/RNA in feces. Our results showed that HIV-1 DNA was detected from normal donor feces mixed with 8E5 cells with the detection limit of 2.5 copies of HIV-1 DNA/reaction. HIV-1 RNA was detected from normal feces mixed with HIV-1 positive plasma with detection limit of 40 copies of HIV-1 RNA/reaction. To evaluate usage of fecal specimens to monitor HIV-1 associated GALT pathogenesis, we collected the feces samples from HIV-1 uninfected and infected donors with or without ART.

In the 49 fecal samples collected in 2007 and 2008, HIV1 DNA was detected in 1 subject from Group B (HIV-1 infected but not on ART) with detectable viral load of 35,471 copies/ml in plasma. HIV-1 RNA was detected in 4 subjects from Group B with viral load ranging between 14,690 and 55,396 copies/ $\mathrm{ml}$ in plasma and in one subject from Group D (HIV-1 infected on ART) with detectable viral load of 16,862 copies $/ \mathrm{ml}$ in plasma. Specificity of the HIV-1 detection was confirmed by amplifying HIV-1 gag region in these env positive samples. In the selected 5 feces samples, identical results were observed in 4 samples with the gag primers. One HIV-1 env positive feces sample was detected negative with gag primers. This might be due to the extremely low copy number of HIV-1 genomes contained in the sample, which could lead to limited PCR detection in the multiple PCR amplifications. Hoek at al[8] reported that no HIV-1 proviral DNA was detected, but HIV-1 RNA was detected in $67 \%$ of subjects' fecal samples by RT-nested PCR. Since the subjects involved in their study were in early stages of HIV-1 infection, when the rapid replication of HIV-1 and destruction of lymphoid tissues occurred in GALT, levels of HIV-1 shedding from GALT to intestinal lumen might be higher compared to the later chronic phase of infection.

The gastrointestinal tract is the major reservoir of viral infected cells and the site of rapid and profound loss of CD4 T cells, which could be the result from HIV direct killing of CD4-expressing primarily infected cells, HIV indirect killing of bystander cells through HIV proteins and/or by the proinflammatory state that is associated to ongoing viral replication[22]. One subset of CD4+ T cells in GALT is Th17 cells characterized by the production of IL-17, which are involved in epithelial regeneration and membrane barrier function. HIV/SIV-mediated Th17 depletion from GALT[23] impairs the gastrointestinal barrier and leads to translocation of intestinal microbes or microbial products, which then contribute to immune activation and disease progression[24,25]. We hypothesize that during CD4 T cell depletion, the depleted cells could shed into intestinal lumen through the impaired GI barrier and be discharged in feces. Because of the persistent active viral replication in GALT, CD4 positive cells are constantly lost from the GI tract throughout infection. Since cells and cellular proteins are degraded very quickly in the lumen of gastrointestinal tract, CD4 mRNA in feces has been monitored instead as a surrogate marker to evaluate CD4 T cells contained in the feces. However, it is possible that some of the detected CD4 mRNA were from macrophages and dendritic cells since these cells express CD4 as well.

All feces samples were screened for CD4 mRNA, a surrogate marker for $\mathrm{CD} 4{ }^{+} \mathrm{T}$ cells. No CD4 mRNA was detected in any feces samples from the HIV-1 negative donors or HIV-1 infected with undetectable plasma viral load, but CD4 mRNA was detected in 5 out of 16 fecal samples from the subjects with detectable plasma viral load, 3 from group B (HIV-1 infected not on ART) and 2 from group D (HIV-1 infected on ART with detectable plasma viral load). These results suggest that $\mathrm{CD} 4^{+} \mathrm{T}$ cells were shed from GALT to intestinal lumen in the infected subjects with detectable plasma viral load.

Detection of blood in feces has long been regarded as an indicator of subject's state of health[26]. HIV-1 RNA/DNA and CD4 mRNA detected in the fecal specimens of HIV-1 infected subjects could be the result either from internal bleeding in the gastrointestinal tract or from shedding of HIV-1 infected cells and free virus from GALT. To dissect these two possibilities, fecal occult blood test was performed in all samples. As listed in Table 3, a total of $7 \mathrm{fecal}$ samples were positive in the test: 2 from Group A, 1 from Group B, 3 from Group C and 1 from Group D. All fecal samples positive for HIV-1 RNA/DNA were negative in the occult blood test. Thus, HIV-1 RNA/DNA detected in the fecal samples could be the result of the shedding of HIV-1 infected cells and/or free virus from GALT into the intestinal lumen.

HIV-1 has been detected in a variety of body fluids and secretions including blood, semen, vaginal fluids and breast milk. Li et al. [17] in 1992 reported the presence of HIV-1 DNA proviral sequences in fresh urine pellets from HIV-1 seropositive individuals. However, the presence of HIV-1 in urine from chronic infected subjects with or without ART has not been addressed. Our data show that 


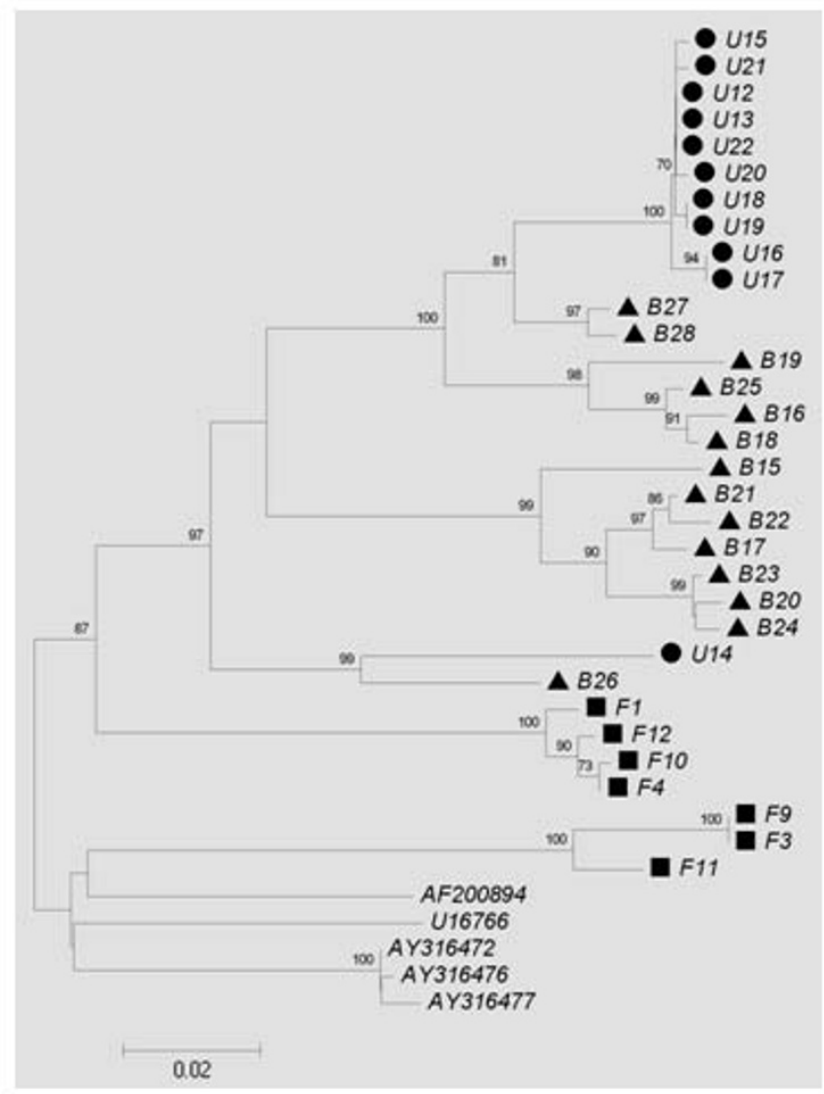

Figure 3

Phylogenetic analysis of HIV-I gp I $20 \mathrm{C}_{2}-\mathrm{V}_{5}$ sequences from blood plasma, urine and feces. Black triangles: sequences from blood; Black circles: sequences from urine; Black square: sequences from feces.

HIV-1 DNA and RNA were detected in both the urine pellet and the supernatant from the HIV-1 infected subjects (Table 3). HIV-1 DNA was detected in 7 urine pellet samples from the 29 HIV-1 infected subjects, 4 of the 7 samples from subjects (2 subjects were not on ART and 2 subjects on ART) with detectable plasma viral load, and 3 from subjects (who were on ART) and with undetectable viral load. This result indicates that the detection of HIV1 in urine is not necessarily associated with plasma viral load.

Due to the tissue-specific anatomical structures and local immunological components, virus replication in different tissues in infected individual could result in the diversity of HIV populations. It has been reported that HIV compartmentalization was present between blood and feces/ gastrointestinal tissues[8-10,27], between blood and urogenital/genital tract [28-30], and SIV compartmentalization between blood and brain/cerebrospinal fluid[31,32]. In this study, the diversity of HIV-1 populations in three compartments (blood, GI tract and urine system) was evaluated. The sequencing analysis of HIV-1 env $\mathrm{C}_{2}-\mathrm{V}_{5}$ region from concurrently collected fecal, urine and blood specimens revealed that HIV-1 compartmentalization was present in the three compartments of this subject.

In summary, this cross-sectional study indicates that the sensitive PCR based method is suitable for HIV-1 DNA/ RNA and CD4 mRNA detection in feces and urine samples from HIV-1 infected individuals. In addition, HIV-1 compartmentalization was revealed in gut, renal system and blood in one infected subject. The presence of HIV-1 RNA/DNA in fecal and urine samples from HIV-1 infected subjects is lesser in the chronic stage of infection compared to the acute stage of infection. Our results suggest that feces could be an informative specimen in clinic for detecting HIV and CD4 mRNA. Since a small sample size was used in the current study, future longitudinal studies are needed to show whether there is a correlation of detection of HIV-1 RNA/DNA and CD4 mRNA in feces with disease progression.

\section{Competing interests}

The authors declare that they have no competing interests.

\section{Authors' contributions}

AC carried out all the feces DNA/RNA isolation and HIV1 detection work and drafted the manuscript. LC, MD and CS performed urine DNA/RNA isolation and HIV-1 detection, the molecular genetic studies and help to draft the manuscript. WB participated in the design of the study and samples collection. YC, PG, and CRR participated in its design and coordination and helped to draft the manuscript. All authors read and approved the final manuscript.

\section{Genebank Accession Numbers}

The genebank accession numbers of the nuclotide sequences reported in this paper are GQ260025GQ260055.

\section{Acknowledgements}

This investigation was part of a thesis submitted by Ayan Chakrabarti in partial fulfillment of requirements for the M.S. degree from the University of Pittsburgh. We thank all Multicenter AIDS Cohort Study participants for donating blood, fecal and urine specimens for this study. We also like to acknowledge Nathaniel J. Soltesz, Brian J. Golgan for collection of biological specimens and Jeffrey Toth for providing clinical information of the study participants.

This work was supported by National Institute of Allergy and Infectious Diseases grants UOI Al-3504I and R37 Al-4I870.

\section{References}

I. Schieferdecker HL, Ullrich R, Hirseland H, Zeitz M: T cell differentiation antigens on lymphocytes in the human intestinal lamina propria. J Immunol 1992, 149:2816-2822. 
2. Brenchley JM, Schacker TW, Ruff LE, Price DA, Taylor JH, Beilman GJ, et al:: CD4+ T cell depletion during all stages of HIV disease occurs predominantly in the gastrointestinal tract. J Exp Med 2004, 200:749-759.

3. Mehandru S, Poles MA, Tenner-Racz K, Horowitz A, Hurley A, Hogan $C$, et al: Primary HIV-I infection is associated with preferential depletion of CD4+ T lymphocytes from effector sites in the gastrointestinal tract. J Exp Med 2004, 200:76I-770.

4. Guadalupe M, Reay E, Sankaran S, Prindiville T, Flamm J, McNeil A, Dandekar S: Severe CD4+ T-cell depletion in gut lymphoid tissue during primary human immunodeficiency virus type I infection and substantial delay in restoration following highly active antiretroviral therapy. J Virol 2003, 77:1 I708-II7I7.

5. Pope M, Haase AT: Transmission, acute HIV-I infection and the quest for strategies to prevent infection. Nat Med 2003 9:847-852.

6. Veazey RS, DeMaria M, Chalifoux LV, Shvetz DE, Pauley DR, Knight $\mathrm{HL}$, et al.: Gastrointestinal tract as a major site of CD4+ T cell depletion and viral replication in SIV infection. Science 1998, 280:427-43I.

7. McCune JM: The dynamics of CD4+ T-cell depletion in HIV disease. Nature 200I, 41 0:974-979.

8. Hoek L van der, Boom R, Goudsmit J, Snijders F, Sol C]: Isolation of human immunodeficiency virus type I (HIV-I) RNA from feces by a simple method and difference between HIV-I subpopulations in feces and serum. J Clin Microbiol I 995, 33:58I-588.

9. Hoek L van der, Sol CJ, Maas J, Lukashov VV, Kuiken CL, Goudsmit J: Genetic differences between human immunodeficiency virus type I subpopulations in faeces and serum. J Gen Virol 1998, 79(Pt 2):259-267.

10. Hoek L van der, Sol C], Snijders F, Bartelsman JF, Boom R, Goudsmit J: Human immunodeficiency virus type I RNA populations in faeces with higher homology to intestinal populations than to blood populations. J Gen Virol I996, 77(Pt I0):24I5-2425.

II. Shepard RN, Schock J, Robertson K, Shugars DC, Dyer J, Vernazza P, et al.: Quantitation of human immunodeficiency virus type I RNA in different biological compartments. J Clin Microbiol 2000, 38: $14 \mid 4-1418$

12. Miles BJ, Melser M, Farah R, Markowitz N, Fisher E: The urological manifestations of the acquired immunodeficiency syndrome. J Urol 1989, 142:771-773.

13. Rao TK, Filippone EJ, Nicastri AD, Landesman SH, Frank E, Chen CK, Friedman EA: Associated focal and segmental glomerulosclerosis in the acquired immunodeficiency syndrome. $N$ Engl J Med 1984, 3 1 0:669-673.

14. Carbone L, D'Agati V, Cheng JT, Appel GB: Course and prognosis of human immunodeficiency virus-associated nephropathy. Am J Med 1989, 87:389-395.

15. Cao Y, Friedman-Kien AE, Chuba JV, Mirabile M, Hosein B: IgG antibodies to HIV-I in urine of HIV-I seropositive individuals. Lancet 1988, I:831-832.

16. Hashida S, Hashinaka K, Ishikawa S, Ishikawa E: More reliable diagnosis of infection with human immunodeficiency virus type I (HIV-I) by detection of antibody IgGs to pol and gag proteins of HIV-I and p24 antigen of HIV-I in urine, saliva, and/or serum with highly sensitive and specific enzyme immunoassay (immune complex transfer enzyme immunoassay): a review. J Clin Lab Anal 1997, I I:267-286.

17. Li J], Huang YQ, Poiesz BJ, Zaumetzger-Abbot L, Friedman-Kien AE: Detection of human immunodeficiency virus type I (HIV-I) in urine cell pellets from HIV-I-seropositive individuals. J Clin Microbiol 1992, 30:1051-1055.

18. Li JJ, Friedman-Kien AE, Huang YQ, Mirabile M, Cao YZ: HIV-I DNA proviral sequences in fresh urine pellets from HIV-I seropositive persons. Lancet 1990, 335:1590-1591.

19. Folks TM, Powell D, Lightfoote M, Koenig S, Fauci AS, Benn S, et al.: Biological and biochemical characterization of a cloned Leu3- cell surviving infection with the acquired immune deficiency syndrome retrovirus. J Exp Med 1986, I 64:280-290.

20. Breitbart M, Hewson I, Felts B, Mahaffy JM, Nulton J, Salamon P, Rohwer F: Metagenomic analyses of an uncultured viral community from human feces. J Bacteriol 2003, I 85:6220-6223.

21. Zhang T, Breitbart M, Lee WH, Run JQ, Wei CL, Soh SW, et al.: RNA viral community in human feces: prevalence of plant pathogenic viruses. PLOS Biol 2006, 4:e3.
22. Sodora DL, Silvestri G: Immune activation and AIDS pathogenesis. Aids 2008, 22:439-446.

23. Brenchley JM, Paiardini M, Knox KS, Asher Al, Cervasi B, Asher TE, et al.: Differential ThI7 CD4 T-cell depletion in pathogenic and nonpathogenic lentiviral infections. Blood 2008, I | 2:2826-2835.

24. Douek D: HIV disease progression: immune activation, microbes, and a leaky gut. Top HIV Med 2007, I 5: I | 4- I I 7.

25. Paiardini M, Frank I, Pandrea I, Apetrei C, Silvestri G: Mucosa immune dysfunction in AIDS pathogenesis. AIDS Rev 2008, 10:36-46.

26. Loitsch SM, Shastri $Y$, Stein J: Stool test for colorectal cancer screening--it's time to move! Clin Lab 2008, 54:473-484.

27. van Marle G, Gill MJ, Kolodka D, McManus L, Grant T, Church DL: Compartmentalization of the gut viral reservoir in HIV-I infected patients. Retrovirology 2007, 4:87.

28. Bull ME, Learn GH, McElhone S, Hitti J, Lockhart D, Holte S, et al.: Monotypic human immunodeficiency virus type I genotypes across the uterine cervix and in blood suggest proliferation of cells with provirus. J Virol 2009, 83:6020-6028

29. Diem K, Nickle DC, Motoshige A, Fox A, Ross S, Mullins Jl, et al.: Male genital tract compartmentalization of human immunodeficiency virus type I (HIV). AIDS Res Hum Retroviruses 2008 , 24:56I-57|.

30. Philpott S, Burger H, Tsoukas C, Foley B, Anastos K, Kitchen C, Weiser B: Human immunodeficiency virus type I genomic RNA sequences in the female genital tract and blood: compartmentalization and intrapatient recombination. J Virol 2005, 79:353-363.

31. Chen MF, Westmoreland S, Ryzhova EV, Martin-Garcia J, Soldan SS, Lackner A, Gonzalez-Scarano F: Simian immunodeficiency virus envelope compartmentalizes in brain regions independent of neuropathology. J Neurovirol 2006, I 2:73-89.

32. Harrington PR, Connell MJ, Meeker RB, Johnson PR, Swanstrom R: Dynamics of simian immunodeficiency virus populations in blood and cerebrospinal fluid over the full course of infection. J Infect Dis 2007, I 96: I058-1067.
Publish with Bio Med Central and every scientist can read your work free of charge

"BioMed Central will be the most significant development for disseminating the results of biomedical research in our lifetime. "

Sir Paul Nurse, Cancer Research UK

Your research papers will be:

- available free of charge to the entire biomedical community

- peer reviewed and published immediately upon acceptance

- cited in PubMed and archived on PubMed Central

- yours - you keep the copyright 